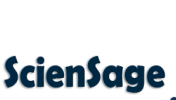

Journal of Advanced Scientific Research

Available online through https: / /sciensage.info
ISSN: 0976-9595

Research Article

DOI: $10.55218 /$ JASR. 202213134

\title{
DEVELOPMENT AND DESIGNING TRANDOLAPRIL TOPICAL FILM FOR MANAGEMENT OF CARDIAC STROKE
}

\author{
More Swapnil Maruti*, Mrunal K Shirsat \\ Department of Pharmaceutical Science, Faculty of Pharmacy, Madhav University, Pindwara, Sirohi, Rajasthan, India \\ *Corresponding author: swapnil.pharma2008@gmail.com
}

\begin{abstract}
Transdermal drug delivery system (TDDs) is novel specified dosage forms, when drug deliver through the skin at controlled rate to the systemic circulation as applied to the intact skin. The present investigation is to prepared transdermal films of trandolapril intended for controlled release polymeric transdermal patch for a care of cardiac patients. The objective of current work is to develop the polymeric transdermal patch for immediate release of drug materials. The transdermal film of trandolapril was prepared by using various combinations of the polymers with solvent evaporation technique. The proposed formulations have a number of variables i.e. plasticizers, penetration enhancers, rate controlling process and adhesion on skin. We may apply biologically active permeation enhancers i.e. Isopropyl myristate, Propylene glycol and Mineral oils etc. The result concluded that polymers chitosan have hydrophilic nature and able to enhance spreadability and dispersibility of the water soluble trandolapril enhanced drug release more than $95.5 \%$ within a $6-7 \mathrm{~h}$ as needed for immediate release. The all evaluation parameters and in-vitro drug release study was used for selection of best polymeric film prepared with chitosan (2\%) and PVP (1\%) as plasticizer for the preparation of single layered transdermal film as first immediate release layer.
\end{abstract}

Keywords:

\section{INTRODUCTION}

Cardiovascular diseases (CVDs) are the leading cause of death globally. An estimated 17.9 million people died from CVDs in 2019, representing 32\% of all global deaths. Of these deaths, $85 \%$ were due to heart attack and stroke. Low and middle-income nations account for about three-quarters of all CVD mortality. Out of the 17 million premature deaths (under the age of 70) due to noncommunicable diseases in 2019, 38\% were caused by CVDs. Most cardiovascular diseases can be prevented by addressing behavioural risk factors such as tobacco use, unhealthy diet and obesity, physical inactivity and harmful use of alcohol. It is important to detect cardiovascular disease as early as possible so that management with counselling and medicines can begin [1]. Heart attacks and strokes are usually acute events and are mainly caused by a blockage that prevents blood from flowing to the heart or brain. The most common reason for this is a build up of fatty deposits on the inner walls of the blood vessels that supply the heart or brain. Drugs having their major action on heart or blood vessels or those used mainly for cardiovascular disorders are designated cardiovascular drugs. They can act directly on the cardiovascular structures or through autonomic/central nervous system, kidney, autacoids or hormones which control cardiovascular function [2]. Oral route is the most preferred route fastens in patient fulfilment; though, oral administration is more prone to hepatic first pass metabolism required higher dose of drug. Additionally, the topical drug delivery offers a direct accessibility to the skin as a target. The development of dosage forms for topical drug delivery is one surrounded by the many challenging areas to prepare the formulation by various scientists [3-4]. Topical formulations constitute a wide range of preparations, both cosmetic and dermatological, to their healthy or diseased skin. Topical drug delivery system has been used for centuries for the management of local skin disorders. These formulations may be solid, semisolid to liquid [5-6]. The potential advantages of transdermal / dermal drug delivery (e.g., minimal firstpass metabolism, patient comfort/compliance, local drug delivery to the skin) have various physical and chemical approaches. Such systems are used to overcome the limiting barrier of drug penetration into the skin [7]. A single layer of polymer having adhesive 
properties act as a reservoir system for drug dispersion. If the drugs under study has no ability to cross the skin, ways must be found to modify the diffusional barrier or increase drug permeability by an alternate method by using chemical enhancers [8-9].

\section{MATERIAL AND METHODS}

\subsection{Determination of absorption wavelength ( $\lambda$ max) by UV spectrophotometer}

The absorption maxima was determined by UV scanning of drug solution under ultraviolet spectrophotometer between 200 to $400 \mathrm{~nm}$ wavelengths offer drug sample i.e. trandolapril. Accurately weighed quantity $(25 \mathrm{mg})$ of drug sample i.e. trandolapril was mixed in volumetric flask containing $25 \mathrm{ml}$ of phosphate buffer (pH 7.4). The solution was sonicated in bath sonicator for 20 mins. The resulting solution was known as StockI, having concentration of $1000 \mu \mathrm{g} / \mathrm{ml}$ solution. $1 \mathrm{ml}$ of Stock - I solution was taken and diluted with phosphate buffer ( $\mathrm{pH} \mathrm{7.4)} \mathrm{up} \mathrm{to} 100 \mathrm{ml}$ in other volumetric flask separately and again sonicated for $20 \mathrm{~min}$. The resulting solution was known as Stock-II, having concentration of $10 \mu \mathrm{g} / \mathrm{ml}$ solution. The resulting solution Stock II was run within the range of $200-400 \mathrm{~nm}$ range in double beam UV spectrophotometer (Shimadzu, UV-1800, Shimadzu Corporation, Japan). The result of UV spectrums of trandolapril was shown in Fig. 1.

\subsection{Preparation of standard calibration curve of Trandolapril in phosphate buffer $\mathrm{pH} 7.4$ solution}

Accurately weighed required quantity $(25 \mathrm{mg}$ ) of drug sample i.e. trandolapril was mixed in volumetric flask

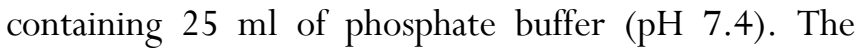
solution was sonicated in bath sonicator for $20 \mathrm{~min}$. The resulting solution was known as Stock-I, having concentration of $1000 \mu \mathrm{g} / \mathrm{ml}$ solution. $1 \mathrm{ml}$ of Stock - I solution was taken and diluted with phosphate buffer $(\mathrm{pH} 7.4)$ up to $100 \mathrm{ml}$ in other volumetric flask separately and again sonicated for $20 \mathrm{~min}$. The resulting solution was known as Stock-II, having concentration of $10 \mu \mathrm{g} / \mathrm{ml}$ solution. Now, for the prepration of calibration curve aliquots of $1 \mathrm{ml}, 2.0 \mathrm{ml}, 3.0 \mathrm{ml}$ upto $5.0 \mathrm{ml}$ were withdrawn from above Stock-II and diluted up to $10 \mathrm{ml}$ with phosphate buffer $(\mathrm{pH}$ 7.4) in volumetric flasks. The concentration of resulting solutions were $10 \mu \mathrm{g} / \mathrm{ml}, 20 \mu \mathrm{g} / \mathrm{ml}, 30 \mu \mathrm{g} / \mathrm{ml}$, upto $50 \mu \mathrm{g} / \mathrm{ml}$ respectively. The absorbance of all resulting solution was calculated individually at $221 \mathrm{~nm}$ with phosphate buffer ( $\mathrm{pH}$ 7.4) as a blank. The absorbance was measured and standard curve was plotted between absorbance vs. concentration. The result of linearity for trandolapril is shown in Table 1 and Fig. 2.

\subsection{Preparation of standard curves of TL by RP-HPLC method}

The method was estimated with isocratic mobile phase using ACN (Acetonitrile): phosphate buffer saline ( $\mathrm{pH}$ 7.4) in the constant ratio of 40:60 v/v throughout the run. The flow rate was maintained at $1.2 \mathrm{~mL} / \mathrm{min}$ during run of samples. The injected volume of drug sample was $10 \mu \mathrm{L}$ and sample was filtered with membrane filter prior to injection in to column. All solutions were protected from light and used within 24 $\mathrm{h}$ to avoid decaying. Standard solutions were prepared separately with mobile phase by different concentrations in the range of $0-12 \mu \mathrm{g} / \mathrm{mL}$ for TL. $10 \mu \mathrm{l}$ injection of each concentration of drug was injected into the $\mathrm{C} 18$ column. Chromatogram of drug was observed with the PDA detector set at $216 \mathrm{~nm}$ wavelength. Standard curve for drug prepared between AUC vs the respective concentration of TL.

\subsection{Standard curve of Trandolapril (TL) by RP- HPLC}

The RP-HPLC chromatogram of pure drug trandolapril is shown in Fig. 3. The standard curve for TL is shown in Fig. 4 and Table 2. A linear correlation was found between AUC and concentration in the ranges 0 to 12 $\mu \mathrm{g} / \mathrm{ml}$ for trandolapril. The retention time was observed as $3.54 \mathrm{~min}$. The $\mathrm{r}^{2}$ of the calibration curve was found to be 0.998 .

\subsection{Preformulation characterization of trando- lapril}

\subsubsection{Sensory identification test}

The sensory identification test of drug sample i.e. trandolapril was performed by using sensory organs. The various sensory identification test parameters are such as color, odor and taste were recorded.

\subsubsection{Phase contrast microscopic study of drug samples}

A pinch of drug sample powder i.e. trandolapril was kept on a glass slide and observed under light effect of phase contrast microscope. The microphotographs were picked to study the nature and texture of the powder and were found to be crystalline in nature. 


\subsubsection{Density}

The drug (Trandolapril) sample powder was accurately weighed and poured through a glass funnel into graduated cylinder and the volume was noted and bulk density was determined. The tapped density was determined using tapped density apparatus. Bulk and tapped densities of trandolapril (TL) were 0.618 $\mathrm{gm} / \mathrm{cm}^{3}$ and $0.676 \mathrm{gm} / \mathrm{cm}^{3}$.

\subsubsection{Particle size}

The particle size of trandolapril drug sample was determined individually by using a phase contrast microscope. It was fitted with ocular micrometer and stage micrometer. The experiment was performed in triplilcate manner and average particle size (mean) was calculated. Trandolapril (TL) mean particle size was found $82 \mu \mathrm{m}$.

\subsubsection{Flow properties}

Carr's index, Hausner's ratio and angle of repose were determined to characterize the flow properties of drug powder. The angle of repose $(\theta)$ was measured by fixed height method. The Carr's index $\left(\mathrm{I}_{\mathrm{C}}\right)$, Hausner's ratio $\left(\mathrm{H}_{\mathrm{R}}\right)$ and angle of repose of drug powder were calculating according to following equation:

Carr's Index $\left(\mathrm{I}_{\mathrm{C}}\right)=\rho_{\text {Tapped }} \rho_{\text {Bulk }} / \rho_{\text {Tapped }}$

Hausner's ratio $\left(H_{R}\right)=\rho_{\text {Tapped } /} \rho_{\text {Bulk }}$

Angle of repose $(\theta)=\tan ^{-1} 2 \mathrm{H} / \mathrm{D}$

Where $\mathrm{H}$ is the surface area of the free standing height of the powder pile and D is diameter of pile that formed after powder flow from the glass funnel.

\subsubsection{4. pH solubility profile}

Solubility of drug trandolapril (TL) was determined separately in aqueous media of different $\mathrm{pH}$. Phosphate buffers of pH 6.8 and pH 7.4 were mixed with Sodium thiosulphate to avoid oxidation. The excess amount of drug sample Trandolapril (TL) was mixed with $100 \mathrm{ml}$ of medium with constant stirring for $12 \mathrm{~h}$ at room temperature, the resulting solution was then filtered with $0.45 \mu \mathrm{m}$ pore size Whatmann filter paper. The drug solubilized in media was determined by analyzing filtered solution by RP- HPLC method. All the procedures were done in triplicate (Table 3).

\subsubsection{Partition coefficient}

The partition coefficient of trandolapril (TL) was determined to predict the hydrophobicity/ hydrophilicity of drug sample. It was determined using mixture of n-octanol: phosphate buffer $(\mathrm{pH}$ 7.4) solution. The mixture was taken $(100 \mathrm{ml})$ in separating funnel, $100 \mathrm{mg}$ of drug was added and shaken for $24 \mathrm{~h}$ until equilibrium reached. Afterwards separating funnel was kept to stand for $2 \mathrm{~h}$ in a stand then both the layers i.e. n-octanol and phosphate buffer were separated and collected individually and filtered. The quantity of drug dissolved in phosphate buffer medium was determined by RP-HPLC method. The amount of drug in n-octanol was obtained by subtracting the quantity of drug in phosphate buffer medium from the quantity of drug taken. The partition coefficient of drug sample was calculated from following equation.

$\log \mathrm{P}(\mathrm{n}-\cot / \mathrm{pH} \quad 7.4)=\log (\mathrm{Coct} / \mathrm{CpH} \quad 7.4)$ equilibrium

The partition coefficient of Trandolapril (TL) was found as 1.39 .

\subsubsection{6. nfrared spectroscopy of drugs}

Drug-excipients interaction/ compatibility studies are performed to ascertain any interaction between drug and selected excipients for formulation design. The fixed ratio of drug and excipients (same as ratio in formulation) were selected and FTIR of mixture was determined and compared with FT-IR of pure drug. Infrared spectroscopy was used to ascertain the functional group present in drug samples. It was carried out using potassium bromide disc method for drug Trandolapril (TL) by Shimadzu IR Spectrophotometer. Drug powder mixed with potassium bromide powder in 9:1 ratio. Disc was prepared by using pressure then placed in sample holder of FTIR and scanned.

\subsubsection{Differential Scanning Calorimetric}

The Differential Scanning Calorimetric studies were performed by using DSC-6100 calorimeter (Shimadzu Corporation, Japan). The study was performed for the estimation of checking drug and Polymer or excipients interactions. The drug samples were heated from 0 to $100^{\circ} \mathrm{C}$ at a heating rate of $25^{\circ} \mathrm{C} / \mathrm{min}$ then instantly cooled to $10^{\circ} \mathrm{C}$ and reheated from 100 to $300^{\circ} \mathrm{C}$ at a heating rate of $10^{\circ} \mathrm{C} / \mathrm{min}$ under the flow of nitrogen. Glass transition temperature $(\mathrm{Tg})$ and melting point (Tm) were calculated and thermograms identified after scanning.

2.5.2.8. Formulation and Evaluation of drug containing films The objective of present study was to prepare transdermal film containing trandolapril able to release drug within short time interval. The sodium alginate and methyl cellulose solutions were prepared 
separately by dissolving the required quantities in distilled water, whereas chitosan solution was prepared by dissolving the polymer in $1 \% \mathrm{v} / \mathrm{v}$ acetic acid solution with stirring at $40^{\circ} \mathrm{C}$. The API trandolapril $(20 \mathrm{mg})$ were dissolved in casing solvent before addition of polymeric solution separately as given in Table 4. The drug polymer mixture was continuously stirred on thermostatic magnetic stirrer at $37 \pm 2^{\circ} \mathrm{C}$. The plasticizers Glycerin/ PVP/ PEG400 were added with stirring. All the solutions were allowed to stand overnight to remove the air bubbles. After completion of stirring, it was sonicated in ultrasonic water bath and poured in petri dishes containing mercury base having circular glass bangles open at both sides. The bottom of the bangle was wrapped with aluminum foil to allow solvent evaporation at $35^{\circ} \mathrm{C}$ (Olven Instruments, India). The films were prepared by solvent casting method. The dried films were separated, cut into circular films of $2 \mathrm{~cm}^{2}$ (4 mg drug), wrapped in aluminium foil and stored in air tight polyethylene bags in desiccators.

\subsection{Characterization of trandolapril containing transdermal film}

\subsubsection{Physical appearance of films}

The parameters i.e. "optical checking, smoothness, color, transparency and flexibility" were observed [10].

\subsubsection{Measurement of polymeric films thickness}

Measurement of polymeric films thickness was performed by utilizing a screw gauge (least count of $0.02 \mathrm{~mm})$ [11].

\subsubsection{Measurement of films weight variation}

Prepared polymeric films were weighed cautiously in triplicate manner and the mean was calculated. The weight of individual films should be within permitted limit the mean weight of films.

\subsubsection{Uniformity or texture of films}

The prepared films were cut as strips. One film was cut from centre and two were cut from other sides. After cutting the strips of films, the length was measured by using scale. There should not be any constriction in films.

\subsubsection{Surface $\mathrm{pH}$ of films}

Digital $\mathrm{pH}$ meter was used to determine the $\mathrm{pH}$ of surface of prepared films. The prepared film piece was cut and kept in $0.5 \mathrm{ml}$ double distilled water and allowed to swell for $1 \mathrm{~h}$.

\subsubsection{Tensile strength of films}

Tensile strength of $2 \mathrm{~cm}^{2}$ film was measured by using fabricated tensile strength apparatus. The films were fixed by tapes and placed in the film holder. A small hole was made in the adhesive tape in which a hook was inserted. A thread was tied to this hook. This hook was passed over the pulley and a small pin attached to the other end to the hold the weights. A small pointer was attached to the thread, which travels over the graph paper affixed on the base plate. The weight was gradually increased from the lowest to the highest until the film was shattered. The weight required to break the film was noted as break force and tensile strength calculated by the following formulae [12-13].

Tensile strength $\left(\mathrm{N} / \mathrm{mm}^{2}\right)=$ Breaking force $(\mathrm{N}) /$ Cross sectional area of sample $\left(\mathrm{mm}^{2}\right)$

\subsubsection{Evaluation of films folding endurance}

Folding stamina of prepared film was ascertained by manual method as cutting a portion of film. The cut piece or portion of film was folded at the same place. The folding procedure was performed repeatedly till the film broke. Folding endurance was calculated by taking mean of the number of times the film was folded at the same place without breaking [14].

\subsubsection{Evaluation of films Moisture content}

The films were weighed, dried with current of air at $60^{\circ} \mathrm{C}$ and were kept in desiccators having calcium chloride at $40^{\circ} \mathrm{C}$ for $24 \mathrm{~h}$. Dried films were then kept at room temperature and temperature $75 \pm 0.5 \%$ Relative humidity $(75 \%$ humidity maintained by saturated solution of sodium chloride during storage till equilibrium, weighed the films and increase in the weight percent was calculated [11].

\subsubsection{Evaluation of films Swelling Ratio}

Films were placed in petri dish having distilled water till the film achieved constant weight, which was ascertained by weighed the film at a certain time interval. Degree of swelling (SR \%) was calculated using the below equation [15].

SR (\%) $=\{$ (Mass of films at time of investigation_Initial mass of films)/ Initial mass of films $\} * 100$

\subsubsection{Evaluation of films Moisture uptake percentage}

Moisture uptake percentage was determined by weighing the piece of film which was carefully cut by knife. It was placed in desiccators for $24 \mathrm{~h}$ at 
temperature $25-30^{\circ} \mathrm{C} ; 75 \%$ Relative humidity, then weighed and calculated moisture uptake property using the below equation.

Moisture uptake percentage of film $=\{$ (Final mass of Film - Initial mass of Film) /Initial mass of Film $\} \times 100$

\subsubsection{Evaluation of films drug content}

Square piece of prepared film $\left(2^{2} \mathrm{~cm}\right)$ was placed in dissolution medium $(100 \mathrm{ml})$ and stirred constantly for 24 hour. The resulting mixture was ultrasonicated for $15 \mathrm{~min}$ and filtered. Filtrate was diluted with same dissolution medium and subjected to HPLC method for drug content determination.

\subsubsection{In vitro skin permeation study}

In vitro drug release study was performed using distilled water in a glass Franz-diffusion cell composed in laboratory. The prepared formulations films $2 \mathrm{~cm}^{2}$ were cut and were uniformly spread onto the cellophane membrane in between donor and receptor compartments of the diffusion cell and were held tightly by springs. The donor compartment was empty, whereas the receptor compartment was filled with $75 \mathrm{ml}$ of phosphate buffered saline $(\mathrm{pH} \mathrm{7.4)}$. The magnetic stirrer was set at $100 \mathrm{rpm}$ and the temperature was maintained at $37 \pm 5^{\circ} \mathrm{C}$. The amount of drug released was determined by withdrawing $5 \mathrm{ml}$ aliquots at different time intervals upto $12 \mathrm{~h}$. The volume withdrawn was replaced with an equal volume of fresh, prewarmed $\left(37 \pm 5^{\circ} \mathrm{C}\right)$ phosphate buffered saline $(\mathrm{pH}$ 7.4). The resulting aliquote was ultrasonicated for 15 min and filtered. Filtrate was diluted with same dissolution medium and subjected to HPLC method for drug content determination [16].

\subsubsection{Drug Release Kinetic Data Analysis}

Several kinetic models have been proposed to describe the release characteristics of a drug from matrix. The following three equations are commonly used, because of their simplicity and applicability i.e. the zero-order model equation (Plotted as cumulative percentage of drug released vs time); First order model (Plotted as cumulative percentage of drug retained vs time) Higuchi's square-root equation (Plotted as cumulative percentage of drug released vs square root of time); and Korsmeyer-Peppa's equation (Plotted as Log cumulative percentage of drug released vs Log time). The slope of the linear curve gives the 'n' value. Peppas stated that the above equation could adequately describe the release of solutes from slabs, spheres, cylinders and discs, regardless of the release mechanism. The value of ' $n$ ' gives an indication of the release mechanism. When $\mathrm{n}=$ 1 , the release rate is independent of time (typical zero order release/case II transport); $\mathrm{n}=0.5$ for Fickian release (diffusion/ case I transport); and when $0.5<\mathrm{n}$ $<1$, anamalous (non-Fickian or coupled diffusion/ relaxation) are implicated. Lastly, when $\mathrm{n}>1.0$ super case II transport is apparent. ' $n$ ' is the slope value of log $\mathrm{Mt} / \mathrm{M} \infty$ versus log time curve.

\section{RESULTS AND DISCUSSION}

The absorption maxima ( $\lambda$-max) of trandolapril $(10 \mu \mathrm{g}$ $/ \mathrm{ml}$ ) in $\mathrm{pH} 7.4$ phosphate buffer solution were found to be at $221 \mathrm{~nm}$ respectively. The spectrum peak point graph of absorbance of drug vs. wavelength is shown in Fig. 1. Trandolapril was estimated in-vitro by reported UV spectrophotometric methods. The reported UV spectrophotometric methods were slightly modified and optimized according to the existing laboratory conditions. The drug was estimated in the dissolution medium ( $\mathrm{pH} 7.4$ phosphate buffer). The calibration curves in the dissolution medium $(\mathrm{pH} 7.4$ phosphate buffer) were prepared with drug solutions of known concentrations. The absorbance was measured and plotted against drug concentration (Table 1 and Fig. 2). The calibration curves show excellent linearity of data as evidenced by the values of correlation coefficients that were found to be greater than 0.99 . The curves were found to be recti-linear in the concentration range $10 \mu \mathrm{g} / \mathrm{ml}$ to $50 \mu \mathrm{g} / \mathrm{ml}$ for the drug. The result of specificity is given in Table 2. The RP-HPLC method was used for estimation of linear correlation between area under the curve and concentration in the ranges 0 to $12 \mu \mathrm{g} / \mathrm{ml}$ for trandolapril. The retention time was observed as $3.54 \mathrm{~min}$. The $\mathrm{r}^{2}$ of the calibration curve was found to be 0.998 and result was shown in Table 3 and Fig. 3-4.

Table 1: Standard curve of Trandolapril in Phosphate buffer $\mathrm{pH} 7.4$ solution $(221 \mathrm{~nm})$

\begin{tabular}{cc}
\hline $\begin{array}{c}\text { Concentration } \\
(\boldsymbol{\mu g} / \mathbf{m l})\end{array}$ & $\begin{array}{c}\text { Absorbance }(\boldsymbol{\lambda} \text {-max } \\
\mathbf{2 2 1} \mathbf{~} \mathbf{m})\end{array}$ \\
\hline 0 & 0 \\
\hline 2 & 0.041 \\
\hline 4 & 0.081 \\
\hline 6 & 0.117 \\
\hline 8 & 0.147 \\
\hline 10 & 0.182 \\
\hline
\end{tabular}


Table 2: Standard curve of trandolapril in $\mathrm{ACN}$ : phosphate buffer saline (pH 7.4) at $\lambda \max 216 \mathrm{~nm}$

\begin{tabular}{cc}
\hline Concentration $(\boldsymbol{\mu g} / \mathbf{m l})$ & AUC (216 nm) \\
\hline 0 & 0 \\
\hline 2 & 144264 \\
\hline 4 & 316478 \\
\hline 6 & 513874 \\
\hline 8 & 696647 \\
\hline 10 & 881514 \\
\hline 12 & 1022285 \\
\hline
\end{tabular}

Table 3: The pH solubility profile of Trandolapril (TL)

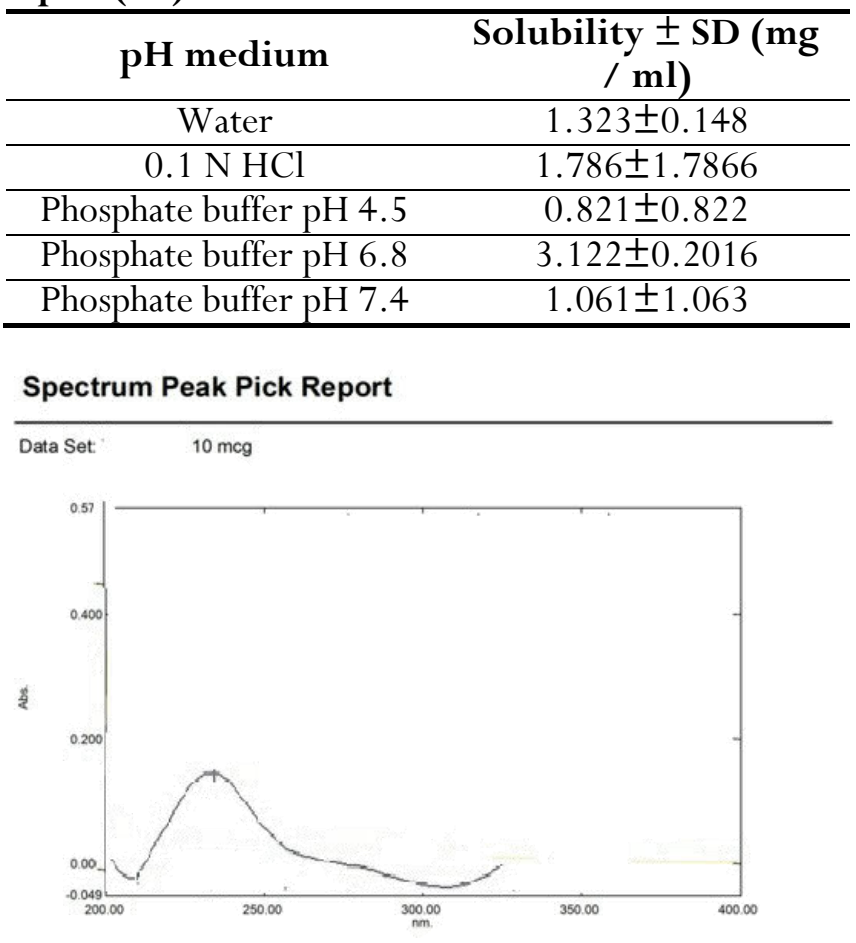

Fig. 1: Absorption maxima ( $\lambda$-max) of Trandolapril in phosphate buffer $\mathrm{pH} 7.4$ solution $(10 \mu \mathrm{g} / \mathrm{ml})$

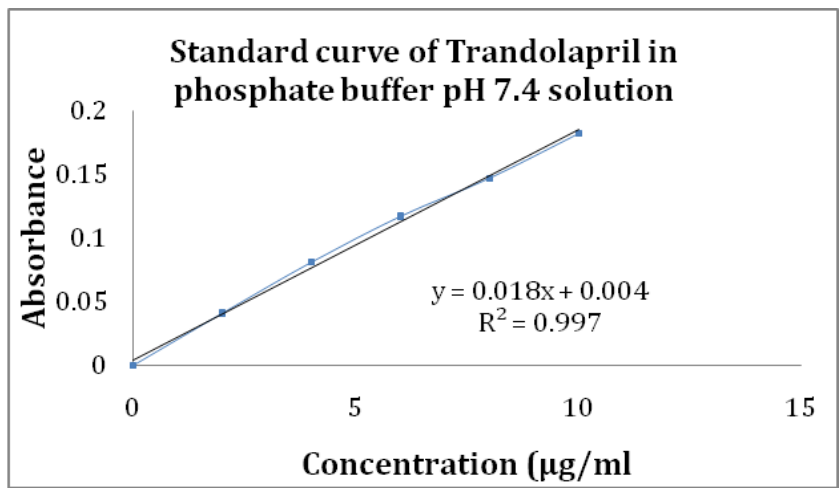

Fig. 2: Standard curve of trandolapril in phosphate buffer $\mathrm{pH} 7.4$ solution $(221 \mathrm{~nm})$

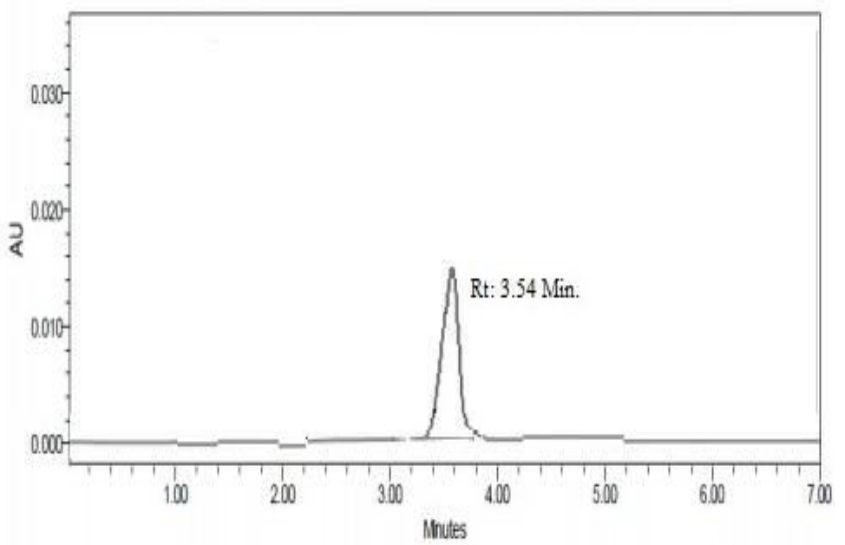

Fig. 3: RP-HPLC chromatogram of pure trandolapril (TL)

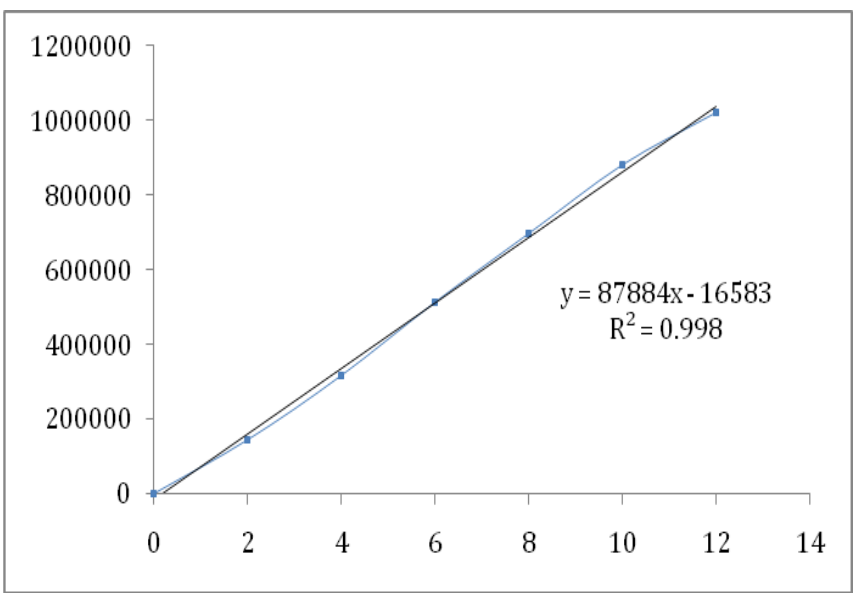

Fig. 4: Standard curve of trandolapril in $\mathrm{ACN}$ : phosphate buffer saline (pH 7.4) at $\lambda \max 216 \mathrm{~nm}$

\subsection{Preformulation studies}

The drug sample Trandolapril was white in color, odorless and slightly bitter in taste. The microphotograph shows that Trandolapril were crystalline in nature. The particle size of unmilled Trandolapril was to be $82 \mu \mathrm{m}$. The result concluded that unmilled powders have good to passable type of flow in nature. The solubility of Trandolapril at Water, $0.1 \mathrm{~N} \mathrm{HCl}$, Phosphate buffer $\mathrm{pH}$ 4.5, Phosphate buffer $\mathrm{pH} 6.8$ and Phosphate buffer $\mathrm{pH} 7.4$ were 1.323 $(\mathrm{mg} / \mathrm{ml}), 1.786(\mathrm{mg} / \mathrm{ml}), 0.821(\mathrm{mg} / \mathrm{ml}), 3.122$ $(\mathrm{mg} / \mathrm{ml})$ and $1.061(\mathrm{mg} / \mathrm{ml})$ respectively. The partition coefficient of trandolapril was found to be 1.93. The interpretation of IR study spectrum is shown in Fig. 5 6. The FTIR spectra of pure Trandolapril illustrated sharp distinctive peaks at 1193 (C-N stretch), 1024 (CC stretch), 1541 (C=C 117 stretch), 1396 (Carboxylate anion stretch), $1735(\mathrm{C}=\mathrm{O}$ stretch $), 3279 \mathrm{~cm}-1(\mathrm{~N}-\mathrm{H}$ 
stretch) and 2879, 2941(C-H stretch). All the above distinctive peaks appeared in the spectra of physical mixture at the same wave numbers representing no alteration or communication between the polymers and drug. The thermogram shown in Fig. 7 have sharp endothermic peak observed between 119.87 to $123.17^{\circ} \mathrm{C}$ which stand for the glass transition temperature of the drug trandolapril. The therogram of drug polymer blend Fig. 8, a peak was observed at $123^{\circ} \mathrm{C}$.

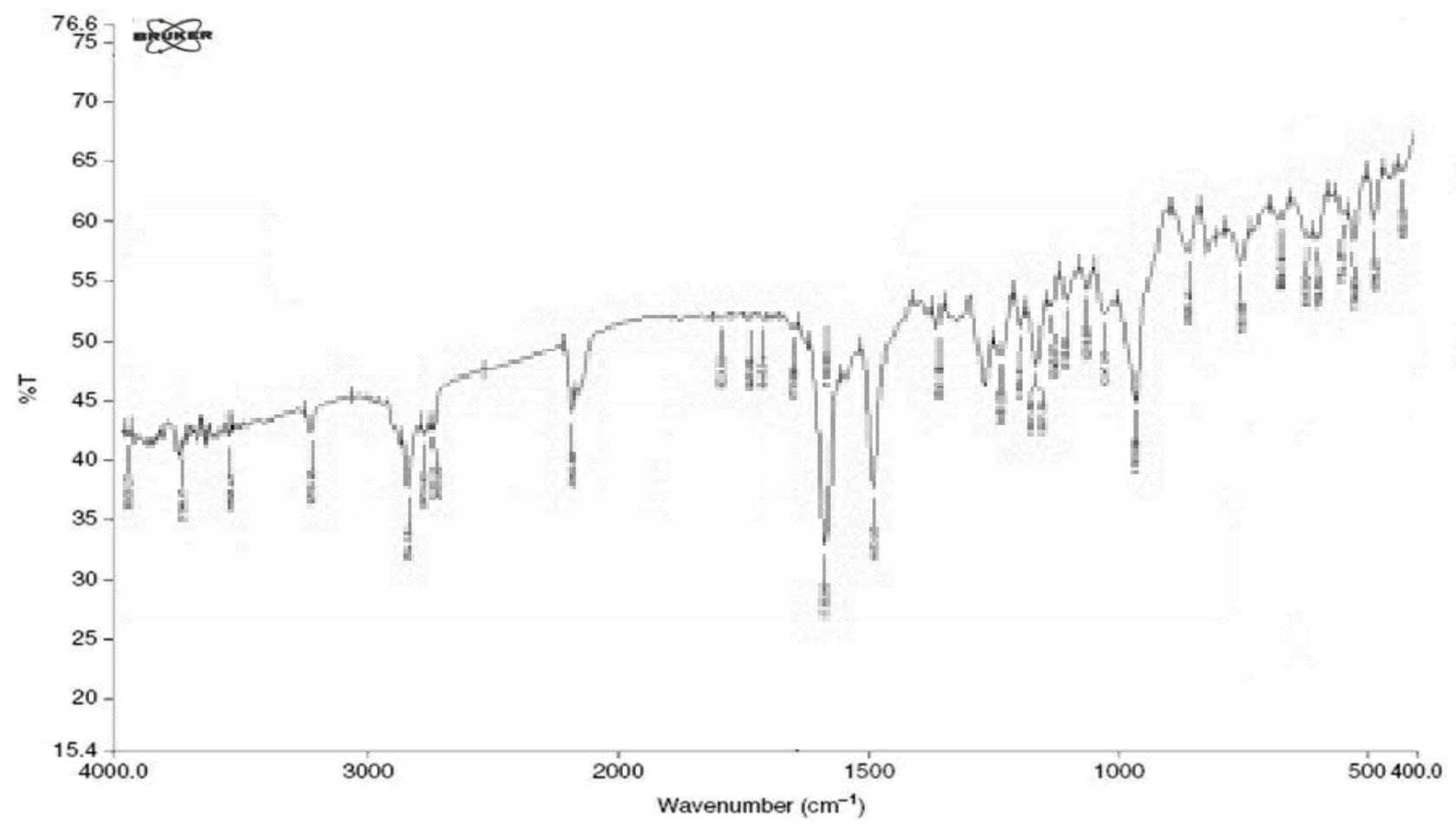

Fig. 5: IR Spectrum of Trandolapril sample (S1)

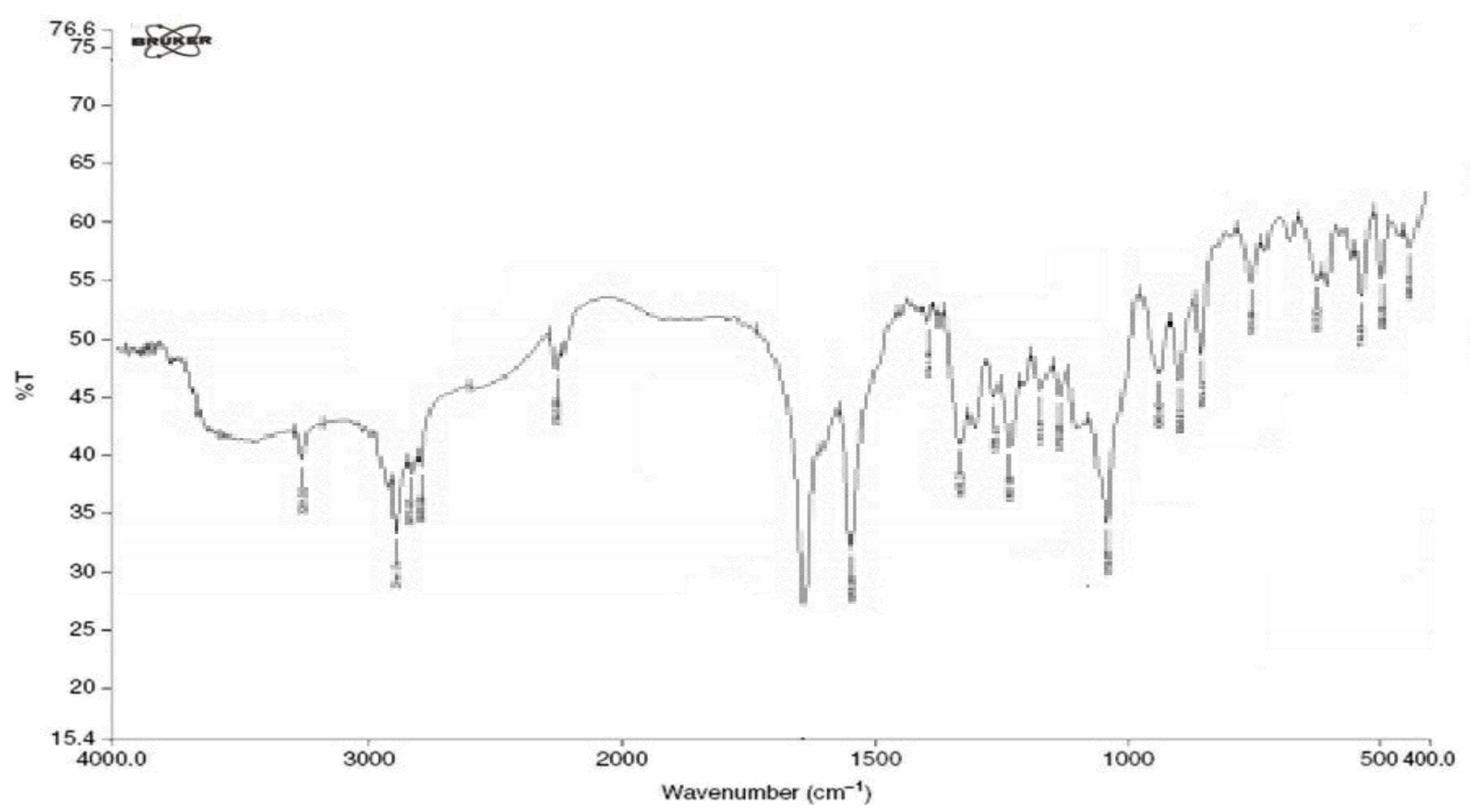

Fig. 6: IR Spectrum of Trandolapril drug and all excipient (S2) 


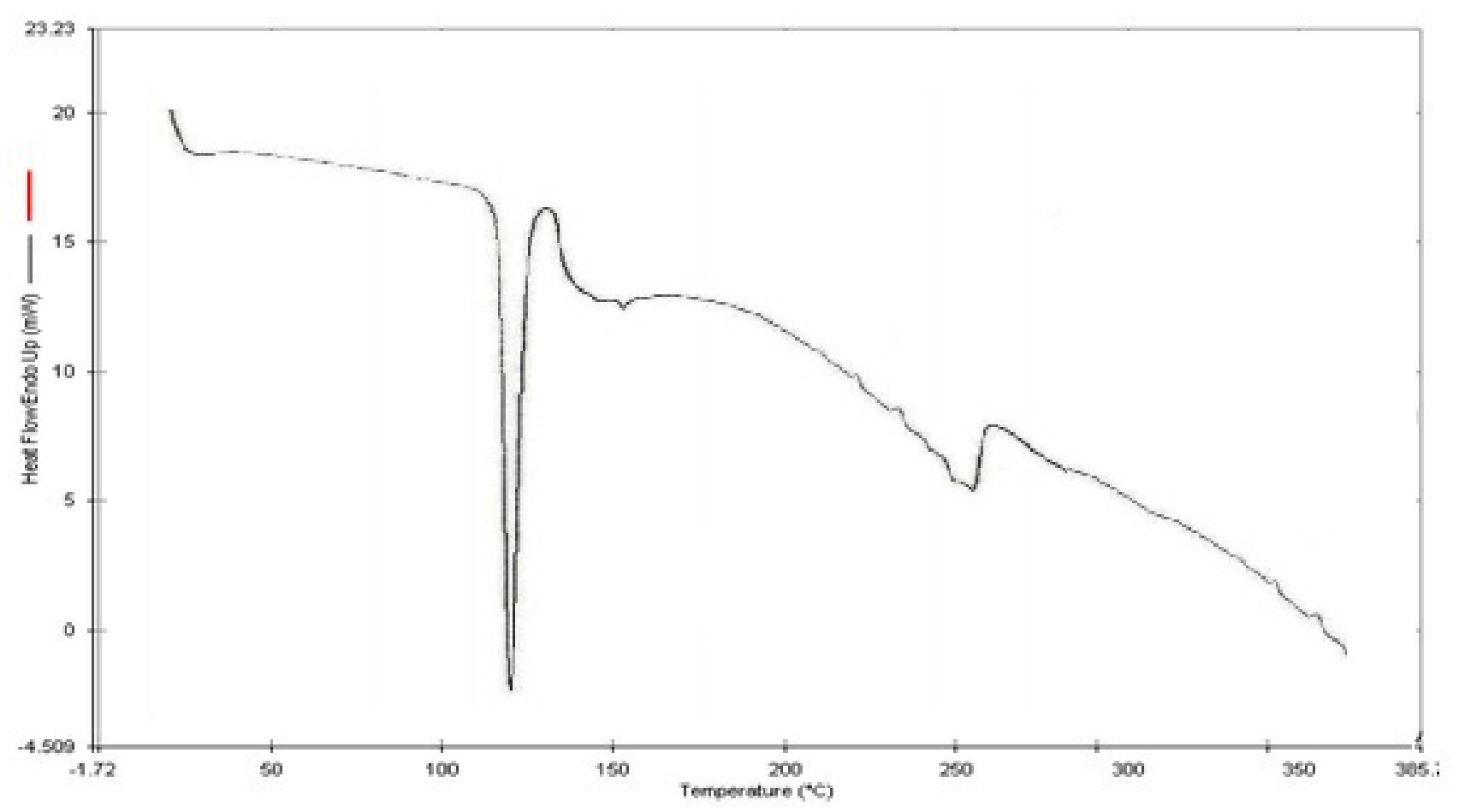

Fig. 7: Differential Scanning Calorimetry (DSC) of Trandolapril

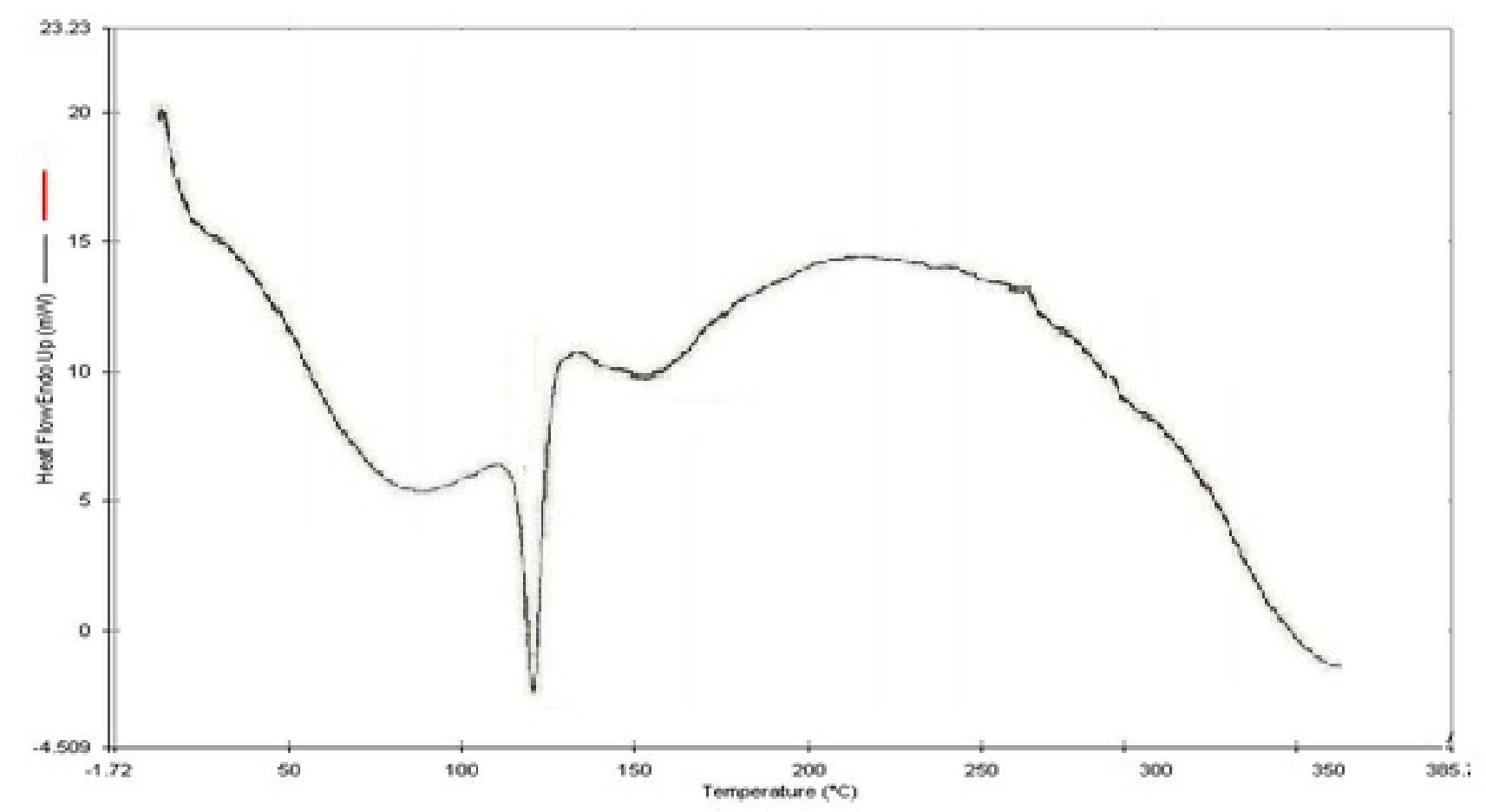

Fig. 8: Differential Scanning Calorimetry (DSC) of Trandolapril and all excipients

\subsection{Characterization of transdermal film}

All the prepared TTF1-TTF9 were flexible, smooth, opaque and non sticky in nature. The result of thickness of patch varied from 0.22- $0.29 \mathrm{~mm}$ of TTF1- TTF9. The result of mass deviation of patch varied from
110.33-119.23 mg of TTF1-TTF9. The result of cracking acceptance power of patch varied from 75-97 $\% \mathrm{~mm}^{2}$ of TTF1-TTF9. The result of percentage elongation varied from $93.74-119.11 \% \mathrm{~mm}^{2}$ of TTF1TTF9. The result of tensile strength varied from 3.66- 
$7.79 \mathrm{~N} / \mathrm{mm}^{2}$ of TTF1-TTF9. The result of swelling ratio varied from 16.63-23.97 \% of TTF1-TTF9. The result of surface $\mathrm{pH}$ varied from 5.5-5.8 of TTF1-TTF9. The result of drug content varied from 93.99-99.74\% of TTF1-TTF9. The prepared Trandolapril films were characterized by a number of optimized parameters i.e. "optical checking, smoothness color, transparency and flexibility, Thickness of polymeric films, Mass deviation of films, Uniformity or texture of films, Surface $\mathrm{pH}$ of films, Tensile strength of films, Cracking acceptance power of films, Water ingestion amount of films, Swelling Ratio of films, Wetness of films" (Table 5-7). The values obtained after the examination identified by in-vitro drug release study (58.34-95.37\%), that polymers chitosan have hydrophilic nature and able to enhance spreadability and dispersibility of the water soluble trandolapril. The hydrophilic polymer layer produces a water-permeable with more hydrated film. Such hydration allows losing the polymer matrix and consequently enhanced drug release more than 95.5\% within a 6-7 $\mathrm{h}$ as needed for immediate release. For the development of a multilayered transdermal patch as the first immediate release layer, all assessment criteria and an in-vitro drug release research were used to identify the optimum polymeric film made using chitosan and PVP as plasticizer. The polymeric films (TTF6) were selected on the basis of its physical appearance, tensile strength, percentage elongation, folding endurance, swelling ratio, moisture content, moisture uptake nature, drug content and in-vitro drug release study parameters. The release kinetic study confirmed the prepared film was followed diffusion kinetics with immediate release within specific time period (Table 8). The release kinetic study confirmed the prepared patch was followed supercase II transport mechanism of diffusion kinetics with sustained release within specific time period. Regression analysis was performed and the $r^{2}$ values suggested that the curves were fairly linear and slope values were computed from the graph. The release exponent " $n$ " values were in the range of 1.033 to 1.169 . The release exponent " $n$ " was $>1.0$ indicating Super-case II transport mechanism and observed deviation from Fickinan mechanism of drug release.

Table 4: Preparation of trandolapril containing transdermal film

\begin{tabular}{ccccccc}
\hline $\begin{array}{c}\text { Formulation } \\
\text { Code }\end{array}$ & \multicolumn{3}{c}{ Polymers (gm) } & \multicolumn{3}{c}{ Plasticizers } \\
\cline { 2 - 7 } & $\begin{array}{c}\text { Sodium } \\
\text { alginate }\end{array}$ & $\begin{array}{c}\text { Methyl } \\
\text { cellulose }\end{array}$ & Chitosan & $\begin{array}{c}\text { Glycerin } \\
(\mathbf{m l})\end{array}$ & $\begin{array}{c}\text { PVP } \\
\mathbf{( g m})\end{array}$ & $\begin{array}{c}\text { PEG 400 } \\
\mathbf{( g m})\end{array}$ \\
\hline TTF1 & 2 & - & - & 5 & - & - \\
\hline TTF2 & - & 2 & - & 5 & - & - \\
\hline TTF3 & - & - & 2 & 5 & - & - \\
\hline TTF4 & 2 & - & - & - & 1 & - \\
\hline TTF5 & - & 2 & - & - & 1 & - \\
\hline TTF6 & - & - & 2 & - & - & 1 \\
\hline TTF7 & 2 & - & - & - & - & 1 \\
\hline TTF8 & - & 2 & - & - & - & 1 \\
\hline TTF9 & - & - & 2 & - & & - \\
\hline
\end{tabular}

Table 5: Physical appearance of films of trandolapril containing transdermal film

\begin{tabular}{ccccc}
\hline Formulation code & Flexibility & Smoothness & Transparency & Stickness \\
\hline TTF1 & Flexible & Smooth & Opaque & Non sticky \\
\hline TTF2 & Flexible & Smooth & Opaque & Non sticky \\
\hline TTF3 & Flexible & Smooth & Opaque & Non sticky \\
\hline TTF4 & Flexible & Smooth & Opaque & Non sticky \\
\hline TTF5 & Flexible & Smooth & Opaque & Non sticky \\
\hline TTF6 & Flexible & Smooth & Opaque & Non sticky \\
\hline TTF7 & Flexible & Smooth & Opaque & Non sticky \\
\hline TTF8 & Flexible & Smooth & Opaque & Non sticky \\
\hline TTF9 & Flexible & Smooth & Opaque & Non sticky \\
\hline
\end{tabular}


Table 6: Characterization of trandolapril containing transdermal film

\begin{tabular}{ccccc}
\hline $\begin{array}{c}\text { Formulation } \\
\text { code }\end{array}$ & $\begin{array}{c}\text { Thickness } \\
\mathbf{( m m}\end{array}$ & $\begin{array}{c}\text { Average weight } \\
\mathbf{( m g )}\end{array}$ & $\begin{array}{c}\text { Folding } \\
\text { endurance }\end{array}$ & $\begin{array}{c}\text { Percentage } \\
\text { Elongation }\end{array}$ \\
\hline TTF1 & $0.29 \pm 0.03$ & $111.32 . \pm 1.154$ & $75-80$ & $93.74 \pm 0.15$ \\
\hline TTF2 & $0.26 \pm 0.02$ & $110.33 \pm 1.156$ & $79-80$ & $94.81 \pm 0.02$ \\
\hline TTF3 & $0.25 \pm 0.03$ & $112.60 \pm 0.144$ & $86-91$ & $101.42 \pm 0.09$ \\
\hline TTF4 & $0.24 \pm 0.02$ & $119.23 \pm 1.154$ & $92-95$ & $116.52 \pm 0.02$ \\
\hline TTF5 & $0.23 \pm 0.01$ & $118.33 \pm 1.155$ & $93-97$ & $118.12 \pm 0.03$ \\
\hline TTF6 & $0.22 \pm 0.01$ & $114.66 \pm 1.165$ & $91-94$ & $119.11 \pm 0.02$ \\
\hline TTF7 & $0.23 \pm 0.03$ & $116.37 \pm 1.154$ & $90-93$ & $95.91 \pm 0.15$ \\
\hline TTF8 & $0.25 \pm 0.03$ & $113.78 \pm 0.111$ & $94-98$ & $104.72 \pm 0.15$ \\
\hline TTF9 & $0.26 \pm 0.02$ & $112.43 \pm 1.152$ & $99-101$ & $102.72 \pm 0.15$ \\
\hline
\end{tabular}

Mean $\pm S D ; n=3$

Table 7: Characterization of trandolapril containing transdermal film

\begin{tabular}{ccccc}
\hline $\begin{array}{c}\text { Formulation } \\
\text { code }\end{array}$ & $\begin{array}{c}\text { Tensile Strength } \\
\mathbf{N} / \mathbf{m m}^{\mathbf{2}}\end{array}$ & $\begin{array}{c}\text { Swelling ratio } \\
\mathbf{( \% )}\end{array}$ & Surface $\mathbf{p H}$ & $\begin{array}{c}\text { Drug content of } \\
\text { films } \mathbf{( \% )}\end{array}$ \\
\hline TTF1 & $3.66 \pm 1.18$ & $23.97 \pm 0.43$ & $5.5 \pm 0.14$ & $93.99 \pm 0.8$ \\
\hline TTF2 & $6.69 \pm 0.23$ & $22.32 \pm 0.39$ & $5.6 \pm 0.14$ & $94.95 \pm 0.9$ \\
\hline TTF3 & $5.93 \pm 0.13$ & $22.18 \pm 0.58$ & $5.7 \pm 0.12$ & $95.79 \pm 0.10$ \\
\hline TTF4 & $6.79 \pm 0.23$ & $21.43 \pm 0.49$ & $5.8 \pm 0.12$ & $99.59 \pm 0.11$ \\
\hline TTF5 & $5.86 \pm 1.18$ & $19.42 \pm 0.57$ & $5.5 \pm 0.13$ & $98.07 \pm 0.12$ \\
\hline TTF6 & $6.13 \pm 0.13$ & $16.63 \pm 0.54$ & $5.5 \pm 0.14$ & $99.85 \pm 0.13$ \\
\hline TTF7 & $5.76 \pm 1.18$ & $20.13 \pm 0.55$ & $5.6 \pm 0.14$ & $97.55 \pm 0.14$ \\
\hline TTF8 & $5.59 \pm 0.23$ & $22.87 \pm 0.46$ & $5.7 \pm 0.14$ & $99.74 \pm 0.15$ \\
\hline TTF9 & $4.63 \pm 0.13$ & $25.48 \pm 0.45$ & $5.6 \pm 0.12$ & $97.99 \pm 0.16$ \\
\hline
\end{tabular}

Mean $\pm S D ; n=3$

Table 8: In-vitro drug release kinetic profile of trandolapril containing transdermal film (TTF1-TTF9)

\begin{tabular}{ccccccccc}
\hline \multirow{2}{*}{$\begin{array}{c}\text { Formulation } \\
\text { Code }\end{array}$} & \multicolumn{2}{c}{ Zero Order } & \multicolumn{2}{c}{ First Order } & \multicolumn{2}{c}{ Higuchi Equation } & \multicolumn{2}{c}{$\begin{array}{c}\text { Korsmeyer Peppas } \\
\text { Equation }\end{array}$} \\
\cline { 2 - 9 } & $\mathbf{r}^{2}$ & $\mathbf{K}_{\mathbf{0}}$ & $\mathbf{r} 2$ & $\mathbf{k}$ & $\mathbf{r}^{2}$ & $\mathbf{K}_{\mathbf{H}}$ & $\mathbf{r}^{2}$ & $\mathbf{n}$ \\
\hline TTF1 & 0.952 & 3.02 & 0.9278 & 0.0811 & 0.983 & 18.22 & 0.822 & 2.201 \\
\hline TTF2 & 0.953 & 3.05 & 0.9268 & 0.0821 & 0.991 & 18.54 & 0.816 & 2.014 \\
\hline TTF3 & 0.961 & 3.02 & 0.9365 & 0.0805 & 0.991 & 19.08 & 0.822 & 2.114 \\
\hline TTF4 & 0.952 & 3.11 & 0.9312 & 0.0804 & 0.988 & 19.11 & 0.817 & 2.201 \\
\hline TTF5 & 0.923 & 3.35 & 0.9411 & 0.0812 & 0.986 & 19.24 & 0.822 & 2.113 \\
\hline TTF6 & 0.922 & 3.05 & 0.9487 & 0.0814 & 0.982 & 19.11 & 0.815 & 2.014 \\
\hline TTF7 & 0.923 & 3.18 & 0.9247 & 0.0817 & 0.991 & 19.87 & 0.814 & 2.221 \\
\hline TTF8 & 0.954 & 3.65 & 0.9125 & 0.0809 & 0.968 & 19.22 & 0.834 & 2.147 \\
\hline TTF9 & 0.956 & 3.06 & 0.9314 & 0.0808 & 0.979 & 19.11 & 0.814 & 2.365 \\
\hline
\end{tabular}

\section{RESULTS AND DISCUSSION}

The proposed model drug Trandolapril is the ethyl ester prodrug of a nonsulfhydryl angiotensin converting enzyme (ACE) inhibitor, trandolaprilat. It is a white or almost white powder with a molecular weight of 430.54. It is soluble $(>100 \mathrm{mg} / \mathrm{mL})$ in chloroform, dichloromethane, and methanol. These proposed TDDs worked on management of diseased of cardiac arrhythmias and have short biological half life, low oral bioavailability value, dose, and molecular weight for better bioavailability of drugs. The transdermal route delivery of trandolapril used for the treatment eliminates major side effects and showed better effect to diseased person. It may relaxes the tone of this smooth muscle, and dilate the blood vessels. The proposed transdermal patch confirmed the immediate release formulation of an angiotensin converting enzyme inhibitor, trandolapril. The findings of this study 
revealed that the problems of hypertension with reported oral formulations for cardiac patients can be overcomed by applying topically in the form of a transdermal patch. Future developments of TDDS will likely focus on the improved management of therapeutic schedule and the continuing extension of drugs offered for use. Transdermal dosage forms may give practitioners an opportunity to offer more therapeutic options to their patients to optimize their care.

\section{Conflict of interest}

None declared

\section{REFERENCES}

1. World Health Statistics 2021, WHO 2021.

2. Tripathi KD. Essentials of Medical Pharmacology, $7^{\text {th }}$ edition, Jaypee Brothers Medical Publishers (P) Ltd, 4838/24, Ansari Road, Daryaganj, New Delhi 2013; pp 539-558.

3. Moser K, Kriwet K, Naik A, Kalia YN, Guy RH. Eur J Pharm Biopharm, 2001; 52:10-112.

4. Jain K, Sethi M. International Journal of Pharmaceutical Studies and Research, 2011; 1: 122-132.

5. Rieger MM, Lachman L, Lieberman Ha, Kanig Jl. Emulsions. The Theory and Practice of Industrial
Pharmacy. 3rd ed. Philadelphia, PA: Lea and Febiger; 1986; 502-533.

6. Chojnicka A, Sala G, Cornelus G. Food hydrocolloids, 2009; 23:1038-1046.

7. Kreilgaard M. Pharmaceutical Research, 2001; 18: 367-373.

8. Tanner T and Marks R. Skin Res \& Tech, 2008; 14:249-260.

9. Aqil AM, Kohli K, Sultana Y, Mujeeb M, Ali A. Asian J. Pharm. Sci, 2010; 5(6): 276-288.

10. Kharia A, Gilhotra R, Singhai AK. International Journal of Pharmaceutical Sciences and Research, 2019; 10:2375-84.

11. Panda DS, Chodhury NSK, Yedukondalu M, Gupta R. Asian Journal of Pharmacy, 2008; 3: 50-52.

12. Khan MZ, Helena PS, Kurjakovic N. Drug Development and Industrial Pharmacy, 2000; 26:549-54.

13. Bindu H, Vidyavathi M, Kavitha K, Sastry TP, Suresh RV. International Journal of Drug Delivery, 2010; 2:173-82.

14. Murthy TEGK, Kishore VS. Journal of Scientific \& Industrial Research, 2008; 67:147-50.

15. Ammar HO, Ghorab M, El-Nahhas SA, Kamel R. AAPS Pharm Sci Tech, 2009; 10:7-20.

16. Bhattacharya A, Ghosal SK. Eastern Pharmacist, 2000; 43(507):109-112. 